\title{
IMMERSING JAPANESE STUDENTS INTO ENGLISH LANGUAGE LEARNING: SONGS, GAMES AND CULTURES
}

\author{
Syafryadin Syafryadin ${ }^{1}$, Saad Boulahnane ${ }^{2}$ \\ ${ }^{1}$ University of Bengkulu, Bengkulu, Indonesia \\ ${ }^{2}$ 2Al Akhawayn University, Ifrane, Morocco \\ *e-mail: syafryadin@unib.ac.id
}

\begin{abstract}
Learning English for Japanese is not as easy as people think. Teachers should provide a way to immerse Japanese students. Therefore, this study aimed to understand how Japanese English teachers immersed students in learning English, what challenges that students and teachers were facing and their perceptions toward the International Work Camp. This case study collected the data from 20 students and 10 teachers from various countries using interviews and an observation checklist. The data were analyzed in several steps, starting from data collection, data reduction, data display to data conclusion. The findings of this study show that Japanese and non-Japanese teachers collaborated to immerse students in attractive teaching ways, such as drilling techniques, gaming, singing, using cards, playing outside, grouping, etc. Besides, teachers also kept motivating and reinforcing them to speak English. Furthermore, students' barriers in speaking were pronunciation, anxiety, grammar, vocabulary, and less practice. Problems were not only faced by students as teachers also had hindrances. Therefore, through the International Work Camp, students could learn to speak English effectively. They could interact with other students and get English speaking competence immersion with several native English teachers. The students also had good perceptions of this work camp.
\end{abstract}

Keywords: Immersion, learning English, the International Work Camp

\section{IMERSI SISWA JEPANG DALAM BELAJAR BAHASA INGGRIS: LAGU, PERMAINAN, DAN BUDAYA}

\begin{abstract}
Abstrak: Pembelajaran Bahasa Inggris bagi orang Jepang tidak semudah yang dipikirkan. Para guru seharusnya menyediakan cara untuk melakukan imersi. Oleh karena itu, penelitian ini bertujuan untuk mengetahui bagaimana guru bahasa Inggris melakukan imersi kepada siswa Jepang dalam belajar bahasa Inggris, mengetahui kesulitan siswa dan guru dan mengetahui persepsi terhadap pelaksanaan the International Work Camp. Metode penelitian ini adalah studi kasus yang merupakan bagian dari penelitian kualitatif. Metode pengumpulan data yaitu melalui wawancara dan observasi. Metode analisis data pada penelitian ini menggunakan tahapan pengumpulan data, pengurangan data, penunjukan data, dan kesimpulan. Hasil penelitiannya menunjukkan bahwa guru yang berasal dari Jepang dan non-Jepang melakukan kolaborasi untuk melakukan imersi kepada siswa dengan cara yang menarik, yaitu teknik drilling, permainan, bernyanyi, menggunakan kartu, bermain di luar kelas, berkelompok, dan kegiatan lainnya. Selain itu, para guru tetap memberikan motivasi dan penguatan kepada siswa untuk berbicara bahasa Inggris. Selanjutnya, masalah yang dihadapi siswa Jepang adalah pengucapan, kecemasan, tata bahasa, kosakata dan kurang latihan berbicara. Masalah tidak hanya terjadi pada siswa, namun juga terjadi pada guru. Untuk itu, melalui the International Work Camp, para siswa belajar berbicara secara efektif, berinteraksi dengan siswa lainnya, mendapatkan pengetahuan yang lebih dari guru bahasa Inggris Native, dan memiliki persepsi yang baik terhadap kegiatan ini.
\end{abstract}

Kata Kunci: Imersi, belajar bahasa Inggris, the International Work Camp

\section{INTRODUCTION}

Speaking is one of the English language teaching parts that is pivotal for students. Harmer (2007, p. 269) asserts that the spoken production element comprises connected speech, expressive devices, lexis and grammar, and negotiation of meaning. Those elements are related to accuracy and fluency in speaking. Speaking competence is an ability of the students to speak. It is a competence to convey the message from one person to another to enhance the speaking skill. In this context, there are seven parameters of speaking competence. They are (1) the phrase or sentences imitation, (2) accuracy (vocabulary, grammar, and pronunciation) and 
fluency (flow of the speech, stress, intonation, and pause) in speaking, (3) conversation response, (4) interactional and transactional use in speaking, (5) interpersonal maintenance, and (6) monologue development in speaking, such as oral presentation, speech and other public speaking (Brown, 2017, p. 141). Moreover, with good speaking competence, students were able to speak well and boost their higher order thinking skill.

Asia comprises several countries that use English as a Foreign Language (EFL) and as a second language (ESL). Japan is one of the countries that adopt EFL. In Japanese educational system, English is a compulsory school subject (Osterman, 2014). The Japanese have a low level of English proficiency, particularly in speaking. According to the Ministry of Education, Culture, Sports, Science and Technology, the Japanese educational policy stipulates that English learning instruction must be introduced to the students in the fifth grade and 8 years before the students study at a university in Japan. Additionally, English speaking competence of Japanese has become the lowest in Asian countries based on the Educational Testing Service. In 2019, Education First found that Japan was still categorized as a low among other Asian countries in terms of the English proficiency as shown in the English Proficiency Index (EPI) Report. This is in line with the report from the Japan Times, which stated that the quality of English teachers in Japan was low. Consequently, it affects students' English skills in Japan. Therefore, English immersion is required in learning English, especially speaking.

Tsunekawa (2019) stated that there are six reasons why Japanese People's English speaking skill is not high. (1) In school, they mainly focus on reading and writing to pass their next test with the teachers' role being only to teach and the students only to take notes. (2) They do not have enough time to practice English speaking even though they have learnt all materials in English classes. (3) They seldom meet native speakers. (4) There are very few chances to watch English videos because many tasks come from other lessons. (5) They are afraid of making errors when speaking in English due to their shyness. Shyness is part of Japan's national character and it is related to the communication in front of many people. (6) The Japanese society does not need English as they have their own language to preserve. (7) Katakana words prevent English skills from developing and (8) the increasing in Wasei Ego or Japanese English blocks students' ability to speak English well.

Many studies on speaking have been carried out, several of which focused on the context of an English camp. Most previous studies focused on investigating the effect of immersing and increasing students' speaking ability through an English camp (Mustakim \& Ismail, 2018; Manan, 2018; Osterman, 2014; Rungsong \& Phawiripiriyakliti, 2018;). While Watcharajinda et al. (2015) only aimed to fulfill the demands of the students who wanted to join an English camp, another study by Okamura (2006) aimed to overcome difficulties in vocabulary learning among research authors in order to better learn English whether for speaking or writing skills. This is almost the same as the study conducted by Rugasken and Harris (2005), who immersed Thai students in English writing activities. Furthermore, Wighting et al. (2006) and Sutherland (2012) aimed to explore teaching and learning dynamics during a summer English language camp. The results of this study show that the students preferred to learn English with native speakers because native speakers provided appropriate strategies in teaching English. Next, Wilson and Sibthorp (2017) examined the role of summer camps in developing academic and workplace readiness, but it is in general not an English camp. Likewise, Azhari and Roslina (2015) aimed to avoid a stagnant situation in developing Sagori Island as an English Camp-based tourism village. Their research focused on the place of the English camp. In short, those previous studies mainly focused on English speaking competence, vocabulary, and writing and most of those studies conducted in Thailand and China. Besides, the results of those studies were not quite satisfactory, given that the students felt bored in some parts. The students joined English camp because they wanted to improve their score in school exams and they preferred vocabulary to speaking. They tried hard to speak and even though some could speak in English, the results were not satisfactory. Furthermore, based on the preliminary observation, the students were poor in English especially in speaking. The students did not have adequate skills or knowledge. Besides, their language structures were different from English, thus they had difficulty learning English.

Therefore, current research integrates culture into an English camp to provide immersion to children and the residents to learn English in Japan, especially to increase the speaking skills in the International Work Camp. Several studies have investigated culture and English language teaching. 
First, Mahardika (2017), Sugirin et al. (2011), Liu and Laohawiriyanon (2013) conducted research on the integration of culture in textbooks, English materials, and public speaking curriculum. The studies aimed at knowing the cultural integration in English materials. Second, Bada (2000), Sardi (2002), Mahmoud (2015), and Choudhury (2014) carried out research on the relationship between culture and English language teaching (ELT), where their results show that culture are closely related to English language teaching because in teaching, teachers can integrate culture in teaching. There was a study that is still in line with the studies done by Tuna and Razi (2016), who investigated how pre-service and in-service foreign language teachers consider the integration of culture in English language teaching. Besides, Jahanforouz (2018) also conducted a study with almost the same theme namely culture and English language teaching, but he added the literature and culture in it.

Third, studies by Jabeen and Shah (2011) and Belli (2018) aimed at knowing the learners' attitude towards culture and English Language Teaching. Fourth, Jin (2018) sought to solve the cultural obstacles when speaking in English in the Korean secondary school context. Fifth, Mejia (2016) conducted a study on the use of Spanish by Hispanic mothers with their children's views on language maintenance and culture. Sixth, Hiep (2006) and Stedman (2006) research aimed at investigating research culture but Hiep (2006) focused on English language professionals, while Stedman focused on a new research paradigm for English studies. Those previous studies were categorized into six groups namely integration of culture in ELT materials, the relationship between culture and English language teaching, learners' attitude towards the implementation of culture in ELT, solutions of cultural obstacles when Speaking in English, language maintenance and culture, and research culture. There are two studies with almost the same theme as the current research namely Wang (2013) and Chu (2007), who sought to explore the role of cultural exchange in educational setting using grounded theory. Chu, on the other hand, conducted research on cultural exchange with a focus on clients with psychological problems.

Current research is different because of the case, the scope, and the research setting. It combines culture and English camp in English language learning. The setting of the International Work Camp was in Gifu. The International Work Camp was one of the programs that provided a chance for lecturers, students or communities to help others based on their field. One of the International Work Camps is Higashi Shirakawa English Village Camp, which is the cooperation result between Higashi Shirakawa Village Board of Education and Nagoya University. The activities of this camp are teaching English to children and residents as well as implementing cultural exchanges, summer festivals, meal presentations and so on. The main aim of this camp is to enhance children and the residents' ability when communicating using English. Furthermore, this research aims to know the teachers' difficulties in doing immersion in speaking and know the students' difficulties in speaking English. This research also aims to know learners and the teachers' perceptions towards the implementation of cultural exchange in relation to improving communication in English and cultural types which might influence students during the communication.

\section{METHODS}

This research used a qualitative case study approach because it aimed to know the portrait and in-depth information from the participants. The research setting was in Gifu, Japan. Gifu was chosen as research setting because the International Work Camp was held there. There were 30 students in Gifu who participated in this research. In particular, there were 20 students and 10 teachers from various countries including Indonesia, Mexico, Malaysia, China, Vietnam, Canada, France, USA, Myanmar, and Switzerland. We employed a purposive sampling technique because of the limitation of the International Work Camp participants. Because this is a qualitative study, it cannot be generalized.

The data collection techniques used were interview and observation checklist. Therefore, we used interview guides to know the students' difficulties when speaking in English, namely vocabulary, pronunciation, grammar, and fluency. The observation checklist aimed to know what the teachers did to immerse Japanese students in English speaking activities.

The data were analyzed using a coding technique while a summarizing technique was used to analyze observation and interview data. Besides, we also applied qualitative data analysis techniques which were done in several steps, such as data collection, data reduction, data display and data conclusion (Miles et al., 2014). In the first step, data were gathered based on the observation and 
interview data. Afterwards, those data were reduced based on the research objectives namely how the teachers immersed the students in English learning activities, their problems and perceptions. In the third step, we displayed the data in terms of description for interview and checklist for the observation. Finally, we concluded the data whether those data were in accordance with the research problems or not. The conclusion was that the data could answer the research questions.

\section{FINDINGS AND DISCUSSION Findings}

The results of this research answered the research questions about what are the English language teachers do in the camp to immerse the Japanese students to improve their English speaking skills? And the Japanese students' difficulties when Speaking in English as well as their perceptions.

\section{English language teachers immersed \\ Japanese students in English speaking activities}

To answer the first research question, it can be based on the observation checklist and notes. They are presented in Table 1 and Table 2.

The English teachers from Japan and Non-Japanese English teachers provided some games and songs for teaching the Japanese students. First, those English teachers collaborated to provide games for the children, such as hide-and-seek game, moving chairs, guessing words and sentences, and presentation. Students felt happy to learn English especially speaking, even though they started to speak using simple sentences. The teachers inserted vocabulary that would be used in speaking for the children in the games. The vocabulary is used in the games, such as "hi, hello, my name, greetings (good morning, good afternoon), good bye, see you, my hobby, my idea and other vocabularies." In the games, during the implementation, the teachers explained the game first, and then they asked the students to do it. The students were enthusiastic and had fun. The teachers immersed Japanese students not only in the classroom, but also outside the classroom. The teachers accompanied the students in learning English while playing games outside the classroom. The students enjoyed it even though it was summer time.

Second, besides games, the teachers also immersed the students by using songs. The teachers and the students sang English songs together. The songs are morning bells, clap hands, and other children's songs. They helped the students practice vocabulary, pronunciation and speaking. The teachers first sang and the students followed. Before the students sang, the teachers asked them to follow and repeat their lyrics per sentence. During the singing, another teacher supervised the students to ascertain all the students followed the instructions. Furthermore, the teachers also mixed between games and singing. In this activity, the students were very happy to join the class. After playing games and singing songs, the teacher asked the students to introduce themselves and described their friends in front of their classmates. Several Japanese students were shy to step forward, but gradually and with encouragement, they eventually did it.

Table 1. Observation Checklist for Teachers in Immersing Students in English Speaking Activities

\begin{tabular}{|c|c|c|c|c|}
\hline No. & Teachers' activities & Yes & No & Notes \\
\hline 1. & $\begin{array}{l}\text { Teachers' collaboration when } \\
\text { teaching the children. }\end{array}$ & & & $\begin{array}{l}\text { Japanese teachers and non-Japanese teachers did } \\
\text { collaborative teaching, played }\end{array}$ \\
\hline 2. & $\begin{array}{l}\text { Teachers provided games in } \\
\text { teaching speaking. }\end{array}$ & V & & $\begin{array}{l}\text { Hide-and-seek game, moving chairs, guessing words } \\
\text { and sentences, and presentation. }\end{array}$ \\
\hline 3. & $\begin{array}{l}\text { Teachers provided songs when } \\
\text { teaching speaking for children to } \\
\text { practice their pronunciation. }\end{array}$ & V & & $\begin{array}{l}\text { Morning bells, clap hands, and other children's } \\
\text { songs from native English-speaking countries }\end{array}$ \\
\hline 4. & $\begin{array}{l}\text { Teachers introduced the culture to } \\
\text { children }\end{array}$ & V & & $\begin{array}{l}\text { Teachers use power point documents to introduce } \\
\text { traditional food from Japan and other countries. } \\
\text { Besides, children are also introduced with traditional } \\
\text { dance }\end{array}$ \\
\hline 5. & $\begin{array}{l}\text { Teachers taught students how to } \\
\text { cook traditional food }\end{array}$ & V & & $\begin{array}{l}\text { Traditional foods from Japan, Indonesia, Spain, } \\
\text { London, Canada, French and other countries }\end{array}$ \\
\hline 6. & $\begin{array}{l}\text { Teachers taught students how to do } \\
\text { Japan traditional dance }\end{array}$ & V & & $\begin{array}{l}\text { Japanese teachers collaborated with the English } \\
\text { native teachers to teach a traditional dance from } \\
\text { Japan. }\end{array}$ \\
\hline
\end{tabular}


Table 2. Observation Checklist for Students in Learning Speaking

\begin{tabular}{|c|c|c|c|}
\hline No. & Teachers' activities & Yes No & Notes \\
\hline 1. & $\begin{array}{l}\text { Students were happy to speak } \\
\text { English with native speakers. }\end{array}$ & $\mathrm{V}$ & $\begin{array}{l}\text { Students were very happy, but one or two students } \\
\text { were still shy when meet foreigners. }\end{array}$ \\
\hline 2. & $\begin{array}{l}\text { Students learned English by using } \\
\text { interactive games to increase their } \\
\text { speaking English. }\end{array}$ & $\mathrm{V}$ & $\begin{array}{l}\text { The games are very fun. The games were done } \\
\text { sometimes in the classroom and sometimes outside } \\
\text { classroom. }\end{array}$ \\
\hline 3 & $\begin{array}{l}\text { Students learned English by using } \\
\text { songs to practice their } \\
\text { pronunciation. }\end{array}$ & $\mathrm{V}$ & $\begin{array}{l}\text { All students like singing a song. Teachers } \\
\text { sometimes used Japanese songs that were translated } \\
\text { into English. }\end{array}$ \\
\hline 4 & $\begin{array}{l}\text { Children learned Japanese and other } \\
\text { countries' cultures. }\end{array}$ & $\mathrm{V}$ & $\begin{array}{l}\text { Students were enthusiastic because the teachers } \\
\text { used an interesting power point }\end{array}$ \\
\hline 5 & $\begin{array}{l}\text { Children learned how to cook } \\
\text { traditional food and speak about it. }\end{array}$ & $\mathrm{V}$ & $\begin{array}{l}\text { Yes, but two or three students could not tell about it } \\
\text { in complete, but at least they tried. Then, some } \\
\text { students mispronounced and forgot the vocabularies }\end{array}$ \\
\hline 6 & $\begin{array}{l}\text { Children learned the procedures } \\
\text { how to do simple traditional dance. } \\
\text { Then, they told in English. }\end{array}$ & $\mathrm{V}$ & $\begin{array}{l}\text { They could remember how to do it, but several } \\
\text { vocabularies were missing. }\end{array}$ \\
\hline
\end{tabular}

Third, the teachers incorporated culture into teaching English for the children or students, the children learnt how to make traditional food from Japan and other countries, learn how to do traditional dances, how to make Origami and of course games from other countries. In this session, the children or other participants were vey delighted to join the lesson because they enjoyed the moment. Several participants were too shy to speak at first before they could eventually do it. The English teachers created a good learning atmosphere using those activities. Students did not only learn English but also promoted the culture. In the summer festival, several students performed the role play of the Japanese themselves. The audience was very excited.

\section{Japanese Students' Difficulties in Speaking}

Based on the observation checklist and field notes during and after the International Work Camp, the findings showed that several students had problems for building self-confidence in speaking. They mispronounced words and used less vocabulary, had poor intonation, stress, grammatical mistakes, and flat expressions. Several students had low self-confidence because they were too shy to speak in front of people. It was still awkward for them to stand in front of their friends. Next, students mispronounced words, such as want (student pronounced went instead of want), introduce (introduce instead of $\backslash$, in-trə-' düs).

Based on the students and teachers' interviews, the students had problems in terms of speaking. Students had problems in speaking in terms of several categories, i.e., pronunciation, vocabulary, practice, anxiety, and grammar.
In terms of pronunciation, the students do not know how to pronounce words in English and have difficulty saying those words, as students 1 , 8, 10 answered: "I am shy to speak and do not know pronunciation ((私は話すことが恥ずか しいです...それに発音がわかりません), $I d o$ not know how to say in English (英語で話し、 さらに文を整頓すればよいかわかりません

), Difficult to pronounce words (発音が難しい 単語)." In terms of vocabulary, the students did not have enough vocabulary to speak English, as students 2, 4, 5 answered: "I do not know words in English (英語の単語がわかりません), many words in English that I do not know the meaning (たくさんの英語の単語がわかりません),

Hmmm ...less vocabulary (う一ん...語彙が少な いです).” In terms of practice, students were too lazy to practice and seldom to study, so it could be an obstacle for them to improve their Indonesian skill. As for students 3, 7 and 9, they said: “never practice (練習をしません), seldom to study (めったに勉強しない), lazy to practice (まじめに練習しません).” In terms of anxiety, some students felt nervous, too shy to speak because they were not used to speaking in front of many people and one of the cultures of Japanese was shy. As for students 1 and 6, they said: "I am shy to speak, nervous to speak (たく さんの人の前で話すことに緊張します).” In terms of grammar, students were hard to arrange sentences with good grammar. Besides, students were confused to learn Indonesian grammar. As in student eight answers, I do not know how to say in English and arrange the sentence.

Furthermore, teachers had problems teaching speaking for Japanese students, such as 
adjusting students' characters, loss of control, discipline, lack of vocabulary, mispronunciation, and low participation. First, the teacher was still adapting with the students' characters because several of them were too shy to speak, so they were passive in the classroom. Regarding teachers' answer no 1 and 6, they said: "I am just still difficult to adjust with the students'...... Sometimes passive". Second, the students were out of control during the game because they ran back and forth. As in excerpt 2, teacher 2's answer was: "students were hard to be controlled during teaching and learning English". Third, some students had lack of vocabulary and pronunciation. They always mispronounced words. As in teacher 4 and 5 answers, "their pronunciation is not quite good even though...". So, "their vocabularies are limited". Fourth, the students sometimes did not come to the international camp because their parents asked them to spend their vocation in another place. Consequently, they did not practice and learn English on that day. As in excerpt 2, teacher 3's answer was: "Some students sometimes did not come to the class because their parents were asking them to do vocation in another place".

Students' and Teachers' Perception during the Implementation of Work Camp Which Integrates Culture into English Teaching

Referring to the interview results to several students, it showed that students could have positive responses towards the implementation of work camp because they thought that through work camp, the students could know about the culture, games, and also learning English. As students said, "I really enjoy the camp because I could know the culture of other countries, .... we learn culture not only from Japan, but also from other countries and could learn English.". Moreover, based on interview results to teachers, they also gave good responses to the International Work Camp because they could teach Japanese students. Then, students also could enjoy the program and could practice their English. As teachers stated, "I am so excited to teach English that integrate culture because the students will learn English and culture itself. It is very useful for teachers and students because students will get much knowledge about the culture and English practice". Therefore, students and teachers had good responses towards this program. This is a positive activity that can give them experiences.

\section{Discussion}

Based on the findings of the study, NonJapanese and Japanese English teachers cooperated to adopt immersion to enhance the students' interest and ability in learning English. Besides, teachers had found problems in teaching speaking to the students in this International Work Camp. For more details, this discussion was divided into three parts based on the research questions of this study. The first, teachers applied immersion to Japanese students by playing English games, singing songs, culture insertion. In English camp activities, students were enthusiastic about playing games and singing songs because those activities made them happy. Those activities could also increase their participation in speaking. Besides, those activities helped them interact among others. It is proven by the notes during observation to the teachers and students: "the games are very fun. The games were done sometimes in the classroom and sometimes outside classroom", "All students like singing a song. Teachers sometimes used Japanese songs that were translated into English". This finding is supported by Ur (2012) who stated that one of the indications of successful speaking activities is when students have a high level of participation in speaking activities. In other words, they were active both in classroom and outside classroom speaking activities.

Teachers also gave reinforcement to students after they did activities because it would build their motivation in speaking. Even though students made mistakes in speaking, the teachers showed patience in encouraging and motivating them. Furthermore, teachers did not only give games and singing activities; they also immersed the students by using pictures or flash cards. Pictures and flash cards are alternatives media for teachers to use because children like pictures or something colorful and visual. So, these media increased their spirit and motivation to speak. Teachers asked them to describe the pictures or flash cards that they chose. The students' responses reflected happiness and positive attitudes. It could minimize their feeling of shyness to speak in front of their friends. These findings are in line with Mustakim and Ismail (2018), who state that media can be a tool for students to increase their abilities in speaking.

Furthermore, culture integration was also made by the teachers to teach English speaking skills. Teachers used traditional foods to introduce students about the culture. The teachers taught how to cook traditional foods in English. 
The first, teachers used power point to talk about it and then, practice it in front of the class. Then, they asked the students to make a traditional food based on their food choice, whether from Japan or other countries. Students were enthusiastic to do it. Majority students could speak how to cook their traditional food. Even though, some students were not maximum in presenting it but it is better than the previous one. Some students forgot the vocabulary, but the teachers helped them to memorize. The culture integration was not only about traditional food, but also traditional dance. The teachers taught them how to do traditional dance from Japan in English. Thus, students knew steps in doing the dance. Teachers wrote vocabularies in relation to it and pronounce together. The students responded to it in a good way. They could memorize the steps in English because the teachers repeat it several times until students could know how to speak about it. Besides, the students also practice how to do traditional dance. They even made a video. This culture integration made them speak English and have fun in learning speaking.

Second, students' problems in learning speaking can be classified into several categories: pronunciation, vocabulary, grammar, practice, and anxiety. In terms of pronunciation, students had difficulty pronouncing English words because they were not immersed into English activities and only had few practices. As two students said, "I am shy to speak...and do not know pronunciation, difficult to pronounce words, and lazy to practice." As information, one of the traits characterizing Japanese people is shyness and so the Japanese students were too shy to speak. Besides, in their country, English is a foreign language. It is already a part of a culture for Japanese people to keep their mother tongue language. As Ur (2012) stated, one of the speaking problems is the mother tongue use. In terms of vocabulary, the students had inadequate vocabulary in speaking. Several students did not know how to say words in English, so when they spoke, they got stuck or had multiple long pauses. As students stated, "I do not know how to say in English and arrange the sentence", "Hmmm ... less vocabulary"

In terms of grammar, students sometimes misused subject, verb to be, and verbs in simple present tense. One of the causes is that Japanese students had low ability in grammar because Japanese language structure is different from that of English. As Richard (2017) stated, three indicators show that students have competence in speaking: good ability in vocabulary, pronunciation, and grammar. In terms of practice, students can practice inside and outside the classroom. However, if they were at home, nobody could guarantee whether they practiced or not. Students did not have a partner to practice with at home or in their surroundings. In terms of anxiety, several students were too nervous to talk because they were afraid of making mistakes and being laughed at by other friends. This second finding was confirmed by the second relevant study conducted by Osterman (2014), who stated that learning speaking can be from English camp, which provides several activities; however, the problems in speaking can also occur, such as linguistic features and fluency. Okamura's (2006) study also showed that vocabulary is the main problem in speaking because if students do not have adequate vocabulary, they face difficulties speaking.

The third, the problems were not only derived from students, but also from teachers. Teachers had problems teaching Japanese students. Those problems were students' characters, classroom management, lack of skills and low participation. Some teachers had difficulty controlling students in the classroom because of students' chaotic behaviors. As one of teachers said, "The students were hard to be controlled during teaching and learning English." They were very active in terms of movement. However, some students were too shy to speak if they were asked to. Teachers tried to control them by dividing them into several groups. Every group was supervised by one teacher. Next, the lack of skills also became a problem because students had difficulties speaking due to their limited vocabulary, poor pronunciation, little practice at home, and inadequate grammatical ability. As one of the teachers said, "Their pronunciation is not quite good even though I have asked them to repeat for pronouncing words, they were difficult to memorize English words. So, their vocabularies are limited." Thus, it caused low participation in speaking. As Ur (2012) stated, students' problems in speaking are low participation, mother tongue use, and inhabitation. The problems of speaking could be from teacher and students. From the teachers, the problem could be from pedagogical knowledge of the teachers themselves.

The problems that occurred to teachers and students could have been anticipated by giving several treatments as what teachers had already done in the International Work Camp, such as 
providing more immersion, inviting some nonJapanese teachers who are from native speaker countries, giving motivation and reinforcement. This is line with what Harmer (2007) said about problem's solution of speaking, namely using interesting techniques, motivating, inviting native speakers, and teachers' collaboration.

The fourth, students and teachers had positive responses to this international program because they felt happy and enjoyed every single activity in this program. Students were very excited about practicing English directly, such as singing English songs or Japanese songs with English translation, playing games from Japan and other countries, cooking traditional food, making Origami, dancing, and other outdoor activities. Students were very happy to learn English, especially speaking inside and outside the classroom. As several students mentioned, "It is fun, I like it. Especially when playing a game from other countries, ... I think, I like it the camp because we learn culture not only from Japan, but also from other countries and could learn English." Moreover, teachers were very interested in teaching students using those activities. They gave positive comments on these activities of this program. The positive responses showed that integrating culture into English teaching had a good impact on students. As several teachers stated, "I am so excited to teach English that integrate culture because the students will learn English and culture itself. For example, in making origami, the students not only describe how to make it, but also learn the culture.", "It is very useful for teachers and students because students will get much knowledge about the culture and English practice." In this vein, Bada (2000), Sardi (2002), Mahmoud (2015), Choudhury (2014) confirmed that integrating culture activities can give positive vibes to students in learning English. In brief, students and teachers showed positive perceptions on this learning English through the International Work Camp because students did not only learn English, especially speaking, but also learn culture. This also occurred to the teachers because teachers added their experiences in teaching English, knowing several students' characters and improve their ability in teaching English.

\section{CONCLUSION}

In line with the research objectives, the conclusions of this research were (1) Japanese teachers and non-Japanese teachers collaborated to immerse students by teaching them with attractive ways, such as drilling techniques, gaming, singing, using cards, playing outside, grouping and etc. Besides, teachers also kept motivating them and reinforcing their English speaking. (2) Students' barriers in speaking were pronunciation, anxiety, grammar, vocabulary, and limited practice. Problems did not only happen to students, but also to teachers, who had several hindrances. Those were students' characters, classroom management, lack of skills, and low participation. These problems must be solved, even though a process is needed because the International Work Camp had limitations in terms of time-only 12 days. In addition, students and teachers had positive feedback on these activities in the work camp. In short, the International Work Camp can be one of the alternatives for the students for learning English. Students would gain much information, knowledge, friends, and experiences.

\section{AKNOWLEDGEMENTS}

We would like to thank the Dejavato Foundation who have helped us in this research both for their funding and psychological support.

\section{REFERENCES}

Abramova, V. S., \& Boulahnane, S. (2019). Exploring the potential of online English websites in teaching English to nonlinguistic major students: Breaking news English as example. Register

Journal, 12(1), 1-12. https://doi.org/10.18326/rgt.v12i1.1-12

Azhari, A., \& Roslina, R. (2015). A feasibility of Sagori island as an English camp. PEOPLE: International Journal of Social Sciences, 1(1), 842-859. https://doi.org/10.20319/pijss.2015.s21.84 2859

Bada, E. (2000). Culture in ELT. Cukurova University Journal of Social Sciences, 6(1), 100-110.

Belli, S. A. (2018). A study on ELT students' cultural awareness and attitudes towards incorporation of target culture into language instruction. Journal of Language and Linguistic Studies, 14(1), 102-124.

http://www.jlls.org/index.php/jlls/article/v iew/819

Brown, H. D. (2017). Principles of language learning and teaching. Pearson. 
Chu, B. C. (2007). considering culture one client at time: maximizing the cultural exchange. Pragmatic Case Studies in Psychotherapy, 3(2), 34-43. https://doi.org/10.14713/pcsp.v3i3.905

Choudhury, R. U. (2014). The role of culture in teaching and learning of English as a foreign language. Express: An International Journal of MultiDisciplinary Research, 1(4), 1-20.

Harmer, J. (2007). The practice of English language teaching (Longman handbooks for language teacher). Longman.

Hiep, P. H. (2006). Researching the research culture in English language education in Vietnam. TESL-EJ, 10(2), 1-20. http://tesl-ej.org/ej38/a10.pdf

Jabeen, F., \& Shah, K. (2011). The role of culture in ELT: Learners' attitude towards the teaching of target language culture. European Journal of Social Sciences, 23(4). 604-613. https://www.researchgate.net/publication/ 260045647_The_Role_of_Culture_in_EL T_Learners'_Attitude_towards_the_Teach ing_of_Target_Language_Culture

Jahanforouz, S. (2018). The role of literature and culture in English language teaching. Research Gate. https://www.researchgate.net/publication/ 324994566_The_Role_of_Literature_and _Culture_in_English_Language_Teaching

Jin, K. S. (2018). Coping with cultural obstacles to speaking English in the Korean secondary school context. The Asian EFL Journal. https://www.asian-efljournal.com/Sept_04_ksj.pdf

Liu, S., \& Laohawiriyanon, C. (2013). Cultural content in EFL listening and speaking textbooks for Chinese university students. International Journal of English Language Education, 1(1), 82-93 https://doi.org/10.5296/ijele.v1i1.2850

Mejia, G. (2016). Language usage and culture maintenance: A study of Spanishspeaking immigrant mothers in Australia. Journal of Multilingual and Multicultural Development, 37(1), 23-39. https://doi.org/10.1080/01434632.2015.10 29931

Mahardika, I. G. N. A. W. (2017). Incorporating local culture in English teaching material for undergraduate students. GC TALE 2017 Conferences

Proceeding, 1-6.

https://doi.org/10.1051/shsconf/20184200 080

Mahmoud, M. M. (2015). Culture and English language teaching in the Arab world. Adult Learning, 26(2), 66-72. https://doi.org/10.1177/104515951557302 0

Manan, A. N. (2018). Commitment, community and bravery: The core activities in endorsing speaking skill by English camp program. English Review: Journal of English Education, 6(2), 77-84. https://doi.org/10.25134/erjee.v6i2.1255

Miles, M. B., Huberman, A. M., \& Saldana, J. (2014). Qualitative data analysis: A methods sourcebook (3rd ed.). Sage.

Mustakim, M., \& Ismail, I. (2018). The influence of English camp in improving speaking skill of english house course students in Maroangin Kabupaten Enrekang. Edumaspul-Jurnal Pendidikan, 2(2), 61-70 https://doi.org/10.33487/edumaspul.v2i2. 10

Okamura, A. (2006). How do Japanese researchers cope with language difficulties and succeed in scientific discourse in English? Interview with research article writers. The Economic Journal of Takasaki City University of Economics, 48(3), 61-78. http://www1.tcue.ac.jp/home1/kgakkai/ronsyuu/ronsyuukeisai/48_3/okam ura.pdf

Osterman, G. L. (2014). Experiences of Japanese university students' willingness to speak English in class: A multiple case study. SAGE Open Journal, 4(3), 1-13. https://doi.org/10.1177/215824401454377 9

Rugasken, K., \& Harris, J. A. (2005). English camp: A language immersion program in Thailand. The Learning Assistance Review, 14(2), 43-51. https://files.eric.ed.gov/fulltext/EJ866925. pdf

Rungsong, P., \& Phawitipiriyakliti, C. (2018). Success level of English communication by students at English camp. International Journal of Management and Applied Science, 4(1), 24-26. 
http://www.iraj.in/journal/journal_file/jou rnal_pdf/14-496-154088200124-26.pdf

Sardi, C. (2002). On the relationship between culture and ELT. Studies about Languages, 3(3), 101-107. https://www.kalbos.lt/zurnalai/03_numeri s/19.pdf

Stedman, G. (2006). Introduction: Cultural exchange: A new research paradigm for English studies. European Journal of English Studies, 10(3), 217-230. https://doi.org/10.1080/138255706009676 97

Sutherland, S. (2012). Real English in Japan: Team teachers' view on nativeness in language teaching. Journal of English Studies, 10(1), 175-191. https://doi.org/10.18172/jes.186

Sugirin, S., Sudartini, S., Suciati, S., \& Nurhayati, L. (2011). A study on cultural integration in the English textbooks for junior high schools. Litera: Jurnal Penelitian Bahasa, Sastra dan Pengajaran, 10(2), 235-246. https://doi.org/10.21831/ltr.v10i2.1167.

Tsunekawa, K. (2019, June 10). The weird truth behind why Japanese people can't speak English. https://livejapan.com/en/intokyo/in-pref-tokyo/in-ueno/articlea0002216/

Tuna, O. K., \& Razi, S. (2016). Integrating culture into ELT classes: What, why, and how? Procedia - Social and Behavioral Sciences, 232, 41-48. https://doi.org/10.1016/j.sbspro.2016.10.0 09
Ur, P. (2012). A course in language teaching practice and theory ( $2 \mathrm{nd}$ ed.). Cambridge University Press.

Wang, A. L. (2013). Collaborative Learning in cultural exchange: Exploring its current and feature. In C. Bădică, N. T. Nguyen, $\&$ M. Brezovan (Eds.), Computational Collective Intelligence. Technologies and Applications. ICCCI 2013. Lecture Notes in Computer Science, Vol. 8083, 562571. https://doi.org/10.1007/978-3-64240495-5_56

Watcharajinda, A., Scheb-Buenner, P., \& Jingwangsa, P. (2015). Needs towards English camp of junior high school students in the lower southern provinces. Proceedings of 7 th International Conference on Humanities and Social Sciences, 11-26. http://fs.libarts.psu.ac.th/research/confere nce/proceedings-7/1/1.2-

Needs\%20towards\%20English\%20Camp $\% 20$ of\%20Junior-High\%20.pdf

Wighting, M. J., Nisbet, D. L., \& Tindal, E. R. (2006). Exploring a summer English language camp experience in China (A descriptive case study). The Asian EFL Journal, 7(4), 1-26. https://asian-efljournal.com/pta_feb_06_mw.pdf

Wilson, C., \& Sibthorp, J. (2017). Examining the role of summer camps in developing academic and workplace readiness. Journal of Youth Development, 13(1), 83104.

https://doi.org/10.5195/JYD.2018.563 